\title{
Founder CEO Passion in Selling the IPO
}

\author{
Michael Howard (Texas A\&M University) \\ Johannes Kolb (University of Hohenheim) \\ Valerie Sy (Texas A\&M University)
}

KEYWORDS: Management, Marketing, IPOs, IPO.

EDITOR'S NOTE: This article was produced in partnership with Strategic Entrepreneurship Journal, a leading academic journal, as part of our effort to highlight some of the cutting edge research being published there.

Are founder CEOs better at telling their company's story? This has been the topic of an ongoing debate among entrepreneurship research scholars. On the one hand, the original founder can bring tremendous passion to the leadership role, showing their excitement in communicating the potential of the new venture. From Sara Blakely at Spanx to Elon Musk at SpaceX, founder CEOs seem to have the ability to represent their ventures in a uniquely compelling way.

At the same time, successfully managing a company through its growth stages may require a very different set of skills. Planning for expansion and establishing key business processes may call for a "professional" CEO. This could involve hiring someone with experience in balancing the messages communicated to customers, investors and other important external stakeholders.

We were particularly interested to learn how the tradeoff between founder and professional CEOs might play out in the IPO process. Going public is a popular path for founders and investors, allowing them to reap the financial rewards of creating a successful startup while also providing a significant capital infusion to propel the growth of the firm. What might matter more - the passionate storytelling of the original founder, or the reassuring messages coming from a seasoned executive?

\section{Our Research}

We studied 2,200 startups, looking at the positive vs. negative tone of the language they used in their press releases and tracking whether they went public. ${ }^{[1]} \mathrm{We}$ also checked which of the ventures retained their founders or hired new CEOs. Interestingly, most startups in our study hired CEO replacements, with professional CEOs leading just over two thirds of the startups in our data. We analyzed the data to see how founder vs. professional CEOs and their communication strategies affected the likelihood of IPO.

Our findings,

(https://onlinelibrary.wiley.com/doi/epdf/10.1002/sej.137

2) published in a recent issue of Strategic Entrepreneurship Journal, show that founder CEOs are very different in the way they represent their startups to the outside world. They are much more active in their communications, generating many more press releases than professional CEOs. Consistent with the idea that founders are more enthusiastic advocates for their firms, these press releases also tend to be much more positive in tone.

The story became even more interesting when we looked at IPO. Generating more press releases and adopting a more positive tone were strongly linked to ventures going public. This shows that the high volume, positive communication strategy is a direct and specific way that founder CEOs boost the chances of IPO, compared to the communication approach of professional CEOs. Identifying this connection helps explain the intuition that founders and their unique communication approach are important to the success of their startups.

\section{Enthusiasm or 'Adult Supervision?'}

We reached out to entrepreneurs and venture capitalists to help us understand our results, asking them for their thoughts on the role of founder CEOs. The idea of founders having passion for their startups really resonated in these conversations. One tech CEO noted about entrepreneurs, "They see it as a manifestation of their being, and that's partly why they're willing to make so much less money and take irrational risks." A Silicon 
Valley venture capital partner had a similar observation on the important qualities of founders, "I think the essential characteristics are enthusiasm and passion to make a difference in society, in a marketplace."

What can we say about professional CEOs in a pre-IPO startup? They can still play an important role. In fact, one of the entrepreneurs we interviewed agreed that professional CEOs, whom he called the "adult supervision" for the venture, can be very important in managing the regulations and reporting requirements of the public offering process. After reviewing our findings, he suggested a way to get the best of both worlds: hiring a professional CEO to replace the founder, but allowing the founder to remain as a director or chairperson while maintaining a visible role in representing the company to the outside world.

Ultimately, it's hard to overestimate the value of passionate entrepreneurial founders. More than anyone else, they care deeply about the image and success of the ventures they create. In the words of one entrepreneur, "it's my baby, and don't you dare call my baby ugly."

[1] We greatly appreciate the funding and support of the Ministry of Education and Research of Germany and the McFerrin Center for Entrepreneurship at Texas A\&M University in conducting this project.

\section{Read More}

Howard, Michael D.; Kolb, Johannes and Sy, Valerie A: Entrepreneurial Identity and Strategic Disclosure: Founder CEOs and New Venture Media Strategy, (https://onlinelibrary.wiley.com/doi/epdf/10.1002/sej.137 2) Strategic Entrepreneurship Journal, October 7, 2020 